\title{
JobStart
}

\section{Part 6 \\ Planning the Interview}

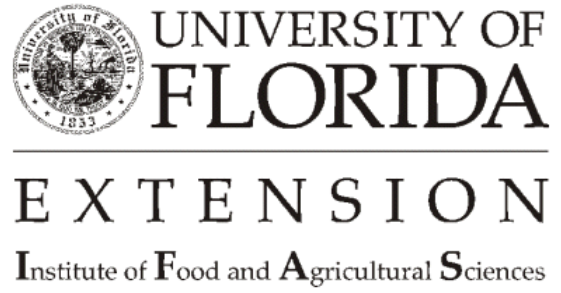




\section{Face to Face Interaction}

The interview is probably the most critical part of the job search process. It brings you face to face with the person or persons that will make the decision as to whether or not to hire you. Usually when you reach the interview stage you have survived the huge screening round. Because interviewing takes up a lot of time, employers don't typically interview more than five to ten candidates. So when you reach this round your odds of being hired have dramatically improved.

In the interview the employer will try to find out if you are really as impressive as your resume and cover letter indicate. It is a test of sorts, where the employer will quiz you in a great many areas, some expected, and some not so expected. The employer is trying to find out why you are choosing his or her organization to seek employment. The employer also wants to know what you can do for the company. The employer also wants to what kind of person you are and if you will fit into the company's work environment.

The interview is not a one way street either. It is your chance to ask the employer some questions about the company to help you decide if you really want to work there. You want to know something about the company's mission. You want to know the specifics of the position for which you are being considered. You want to know if your particular skills will fit into the scheme of the company. You want to know something about the benefits. You want to know something about the upward mobility. You also want to know what your salary will be.

The interview is almost always the last step in the hiring process. In the interview the job is yours to either win or lose. That is why you must master the art of interviewing if you want to win the job you've always wanted.

In this publication we will cover several key aspects of the interview that can make the difference in winning, or losing, the job you want.

\section{Speak with Conviction and Clarity}

One of the first things an employer will notice about a candidate is how well he or she can communicate. How you communicate will influence the employer's impression of your skills, your personality, and your knowledge.

The best way to communicate clearly is to choose your words carefully. You should slow down your speech. Speaking too rapidly can make you appear nervous while at the same time not allow you time to think about what you want to say as you are saying it. Don't try to use large, multi-syllable words to impress the employer, but rather use basic words to express your thoughts clearly.

Never use jargon unless it is common in your field or the field for which are interviewing.

Avoid slang and street words. These types of words can make an individual seem like a poor communicator. 
Try to use correct grammar when you are speaking to the employer. Make sure that your subjects and verbs agree. For example: don't say “ My supervisor love my work." Say “ My supervisor loves my work." Don't use words like "ain't" or double negatives like "He don't give no raises."

While you want to communicate your idea completely, you also want to avoid being long-winded. Try to be as brief with your answers as you can. Don't go off on tangents or lead your answer to unrelated topics. Stick to the point.

The reverse of being long-winded is being too blunt, and this also should be avoided. Don't give short one or two word answers that require a complete answer. For example: If you were asked about your typing skills, you wouldn't say that they were "excellent," and just leave it at that. You would want to elaborate on how many correct words per minute you can type on both a typewriter and the computer.

When speaking, speak so that you can be heard, but not too loud, giving an impression that you are hard of hearing.

Sometimes lowering your voice a bit can give a more professional impression.

Never let a silence fall during the interview. Silence on your part can be misinterpreted as anger or hostility.

Lastly, never interrupt the employer when he or she is speaking. This is a social rule that must not be broken in the interview.

You should never ask for permission to speak. When it is time to speak, jump right in and deliver your message.

One of the best ways to improve your communication skills in an interview is to either record yourself answering sample questions or to have a friend ask the questions and listen to your answers. This is a great method to elevate your speaking habits and help you win that job.

\section{Questions You Will Be Asked}

When answering any interview questions there are some basic principles to keep in mind in order to give appropriate responses. They are as follows:

1. Keep a positive attitude. When responding to questions always focus on the positive aspects like your strengths. Don't get caught in the trap of saying negative things about yourself. 
2. You should keep all responses job related. Never go into your personal life; always keep the focus on the job.

3. You should think about what the employer is trying to find out about you. If an employer asks you why you left a previous job, he or she is trying to find how long they can expect you to stay with this new job. You should ease their fears with an appropriate response.

4. Always give examples. If an employer asks you about how you respond to supervision, give an example of a positive experience you had with a supervisor at a previous job.

5. Get to know the company. If you gather as much information as you can about the company this will help you direct your responses in the interview.

The following are frequently asked questions in employment interviews:

- How do you handle criticism?

- Why are you interested in this job?

- Why should I hire you?

- Would you be willing to take a drug test?

- $\quad$ Do you prefer working with others or alone?

- $\quad$ Do you smoke?

- What skills do you bring to this job?

- How do you perform under stress?

- What kinds of equipment can you operate?

- How was your relationship with your last employer?

- What hours are you available?

- $\quad$ Are you available for overtime?

- Can you tell me about your accomplishments? 
- What are your career goals?

- What do you do with your time off from work?

- Why is there a gap in your job history?

- Why did you leave your last job?

- Why do you want to work here?

- $\quad$ Can you tell me about your weaknesses?

- $\quad$ Can you tell me about yourself?

- $\quad$ Have you ever been fired from a job?

- Have you ever been disciplined by a supervisor?

- $\quad$ Can you supervise others?

- What is your management style?

- How much do you expect to earn?

- What do you enjoy about this line of work?

- What does it take to be successful in this field?

- What causes stress for you?

- What are your priorities in life?

- Can you tell me about your education?

- What would you do if you caught your supervisor stealing?

- $\quad$ Are you a punctual person?

- Can I contact your current employer?

- $\quad$ Have you ever been arrested? 
- Do you need any special requirements to perform your duties?

- What makes you better than the other candidates?

\section{Handling Off-Limit Questions}

Most employers know that there are boundaries that they cannot cross during the interview. Those boundaries include many aspects of your personal life, questions about your age, religion, race, ethnic background, and your family. In fact it is against the law for employers to base hiring on these areas. However, this still does not stop employers who are either unaware of the boundaries or those who choose to disregard them from asking questions that trespass into these territories.

When an employer asks a question about one of these areas you do not have to answer, but that would probably hurt your chances of getting the job. If you really want the job, there are ways around these issues.

One thing you don't want to do is to remind the employer (assuming he or she is unaware of the law) of the boundaries. This could hurt your chances of getting the job.

If an employer asks an off-limit question there is usually a concern that he or she might have. Let's say that you are in an interview and you are a divorced female with two children. It is generally believed in the business world that women with children tend to miss work more frequently. So if the employer asks you questions regarding your marital status and your children, it is probably because there is some fear that you will miss work more frequently. The issue for the employer isn't your personal life, but rather how your personal life will affect your work. The way for you to handle this type of question is to state that yes you are single and have children, but that you do not let them interfere with your work habits. You might state that you have good childcare arrangements and that you have a good track record of work attendance. You should not go into detail about your personal life, but you should offer a brief answer and then try to calm the fear of the employer.

\section{Why You Should Ask Questions}

There are many ways an employer can use to find out what type of person or worker you are, especially in the employment interview. However, there is one method that most job candidates never consider. That is the type of questions the candidate asks during the interview.

By the type of questions you ask during the interview an employer can determine just how thorough and detail oriented you are. The employer can also tell whether you are serious about your employment with the company by the types of questions that you ask.

Many candidates are afraid to ask questions in the employment interview because they are worried they might offend the employer or annoy the interviewer. While you shouldn't badger the employer with 
inappropriate questions in an aggressive manner, you should use a friendly and polite manner to inquire about the company and the position for which you are applying. This will impress the employer and let him or her know that you are professional and want to work for a professional company.

There is another good reason to ask questions in the employment interview, and that is because you also have to make a decision as to whether you want to work for the company or not. You need to know if you will fit into the company's scheme and if you will be happy working for them. You need to know if the salary and benefit package meet your needs. You need to know if the opportunities available within the company will meet your professional growth needs.

In today's business world many companies experience a high level of turnover among employees. During the eighties a large number of companies went through a period of down-sizing, laying off many thousands of workers. This forced the attitude of American workers to change as many long time employees who had worked their way up through a company suddenly found themselves cast out of the companies they had given their loyalty to for so many years. Today in the nineties workers are less likely to generate that same loyalty to employers that they once gave so easily. Workers are more mobile, moving from company to company in order to gain status, greater salary, or better training. This costs employers money, because they are the ones who will spend money on recruiting and training new employees to replace the ones they lose. This is why employers favor candidates who ask questions. They don't want to hire a new employee, spend money to train and equip you, and then lose you because you decide that you aren't happy with the job. So when you get to the interview and the employer gives you the opportunity to ask questions, ask away!

\section{Questions to Ask and Questions to Avoid}

Here are some sample questions that you might ask an employer during an interview.

- Why is this position vacant?

- What is the possibility of advancement?

- $\quad$ May I see a job description?

- Do you think the job will change in the future?

- Would you describe a typical day on the job?

- What are the department goals?

- What is the turnover rate? 
- Why do people like working here?

- Is further education required for the job?

- What is the company's philosophy?

- What is the company's management structure?

- What is the next step after the interview?

There are a few questions that you should avoid during the employment interview. These are questions that could hurt your chances of winning the job you want.

First, if you are going to ask questions about salary and benefits, ask them near the end of the interview.

You should never ask questions that show any type of insecurities you might have about keeping a job. Be quiet on this issue.

Avoid questions that reveal your weaknesses such as "What would happen to me if I had a disagreement with my supervisor?" or "What if I fail to pass the training program?" These will cause the employer to think that you anticipate having these types of problems.

Also, do not ask a question about something that has already been covered in the interview. This will cause the employer to think that you weren't paying attention.

Finally, don't ask questions where the answer is found in literature about the company, and the employer has previously supplied that literature to you.

\section{Tips for the Interview Experience}

Make the interview a positive experience. When you are called for an interview, you naturally want to make a good impression. Listed below are some tips for presenting yourself in a positive manner.

1. Be prepared to tell the interviewer why you should be hired. This means telling him/her what your strengths are. If you have weaknesses, tell the interviewer what you are doing to correct them.

2. Come to the interview ready to give examples of work performed, leadership abilities, and skills you possess. These may or may not be obvious in your resume or job application. 
Enter the interview room briskly. Don't be timid. Introduce yourself to those present; offer your hand. When greeting the interviewer, use his or her name, with Mr., Ms., Dr., etc.

3. Remember to smile and to look the interviewer in the eye. Pay attention at all times.

4. Be yourself in the interview. Be honest about your experiences and education.

5. Avoid short answers that don't provide enough information. Do not assume the interviewer will ask you the right question to get more information.

6. Let the interviewer bring up the issues of salary, benefits, and raises.

7. Ask the interviewer when you can expect to hear about the hiring decision.

8. After the interview, write a personalized thank you note to the interviewer.

\section{Tips for Avoiding Mistakes in the Interview}

Just as you want to have a positive experience in the interview, there are some things that you can control to keep from having a negative experience. Follow these tips to avoid a negative presentation of yourself in the interview. Decide how you can avoid each of these mistakes in the interview.

- $\quad$ Arriving late for the interview.

- Using slang words when answering questions.

- $\quad$ Saying negative things about former employers.

- $\quad$ Chewing gum or candy during the interview.

- $\quad$ Taking someone else to the interview.

- $\quad$ Expecting the employer to know the skills listed on the resume.

- Volunteering negative information.

- $\quad$ Poor body language.

- Volunteering personal information.

- Not having questions to ask the employer. 
- $\quad$ Not having an extra copy of the resume to give the employer.

- $\quad$ Not being neat or well groomed.

- $\quad$ Not being prepared for the interview.

Adapted by: Elizabeth Bolton, Department of Family, Youth and Community Sciences; Institute of Food and Agricultural Sciences; University of Florida; Gainesville, FL. Adapted from: Talham, K. and Gentry, J. (Editors). Summer, 1997. The Latest Word. Tips for Making an Interview Experience Positive. In UF Perspective. Gainesville, FL: University of Florida Personnel Services.

\section{Checklist for Successful Interviews}

To evaluate your interviewing skills, ask yourself these questions. It would be helpful to role play an interview with a friend or relative and have them help you with the evaluation.

\section{Interpersonal Skills - Am I}

Not assertive? Withdrawn?

Approachable? Slightly reserved?

Warm? Sociable?

Very sociable? Outgoing?

Assertive? Extremely outgoing?

2. Stability - Am I

Jumpy? Nervous?

Tense? Irritated?

Somewhat poised? Average?

Confident?

Well composed?

\section{Maturity - Am I}

Immature? Not realistic?

Slightly immature? Impulsive?

Mature? Even keeled?

Good at judging?

Extremely mature? 


\section{Communication Ability - Do I}

Talk very little?

Ramble?

Exhibit average fluency?

Talk to the point?

Have excellent expression?

\section{Motivation - Do I}

Have no defined goals?

Have goals that are too low?

Have appropriate goals?

Have high goals?

Have a plan to achieve high goals?

6. Attitude - Do I have

A negative outlook?

An indifferent outlook?

A good outlook?

A very positive outlook?

An extremely positive outlook?

\section{Overall - Are my interviewing skills}

Unsatisfactory?

Substandard?

Average?

Above average?

Outstanding?

\section{Dress Codes for Men and Women}

The number one reason people are not hired is because of personal appearance. This is why it is important to look your very best when going into an interview. You should avoid fads and outdated styles, and most of all be clean and well groomed. The following is a list of helpful hints to help you make the right impression with your appearance. 
- Wear clothes that fit you well.

- Be conservative in your choice of clothes, avoiding wild colors and designs.

- $\quad$ Decide which color is best for you---gray, blue, and black are good choices.

- $\quad$ Dress better than you would if you were going to work.

- $\quad$ Look in a full length mirror before leaving home.

- $\quad$ Try to get all your clothing items to match, like shoes, belt, pants, shirt, etc.

- $\quad$ Do not wear sunglasses.

- $\quad$ Choose a hairstyle that works best for you.

- $\quad$ Apply perfume and make-up conservatively.

- If you have a suit, wear it.

- Wear brown or black shoes if you have them, avoid sneakers.

- $\quad$ Avoid blue jeans or pants with holes in them.

- Wear a button-up shirt versus a pull-over shirt.

- White shirts tend to give a business appearance.

- $\quad$ Make sure the clothes you are wearing are clean and pressed.

- $\quad$ Always wear a belt with slacks.

- Never wear a hat to an interview.

- $\quad$ Avoid excessive jewelry like big earrings and bracelets.

- If you wear a dress, make sure it is of conservative length.

- Wear hose when wearing a dress.

- A tie is always recommended.

- When in doubt, always overdress rather than underdress. 


\section{Body Language}

Picture for a second that you are an employer conducting a job interview. Across the desk from you is a young man in his twenties who is a candidate for the clerk position you need to fill. He is slouched down into the chair with his right foot propped against your file cabinet. Instead of looking at you he is looking at the floor, the walls, the ceiling, the picture on your desk, anything but you. He is also picking at the fabric in the chair with one of his hands. He does this even though he isn't looking at the chair. You have completed your introductions and have his very impressive resume in front of you. You are about to ask him the very first of your long list of questions. You are going to ask him about his impressive resume. Are you going to think of him as the same professional that is described in the resume? Is anything he says going to be affected by his body language, no matter how well he responds to your questions?

Body language is a very important part of communication, it affects everything we say, and this is especially true in the employment interview. It is a part of the delivery of our words and can either add to the impact of our message or take away from it.

There are many books written on the topic of body language, and each of them covers the many situations where body language plays key roles. For our purposes here we will adjust you to the situation of the interview and recommend the body language that is most effective in helping you win a job.

Let's start with posture. Posture is a big communicator of a person's attitude. It can indicate your energy and enthusiasm. When in the interview sit up and lean forward just a bit. This is usually interpreted by employers to mean that you are excited about the job. Never slouch or sink into a chair. You should change your posture from time to time to avoid sitting perfectly still.

Never fidget in an interview. This is a sign of a nervous candidate and can be interpreted poorly. Watch your hands and feet; if they wiggle, bounce or are otherwise occupied with a nervous habit during the interview, it can be distracting to the interwiewer.

When you are listening or talking to the interviewer always keep eye contact with him or her. Keeping eye contact is a sign of honesty and confidence. Not keeping eye contact can indicate low motivation, low interest, nervousness, or even dishonesty.

If you are a person who excessively talks with your hands, you will want to work on curbing this habit slightly. On the other hand, if you are a person who is motionless when speaking, you will want to work on livening up your speech. Complete stillness when speaking is a sign of low energy. Keeping some of these suggestions in mind it is a good idea to practice interviewing with a friend who can evaluate objectively your communication skills. This will help you to improve on your weaknesses and build up your strengths, helping you to win the job you want. 


\section{Rating the Interview}

Some employers use an interview rating sheet after the interview is over. The following is an example of a rating sheet that an employer might use. Which category do you belong in?

Interview Rating Sheet

\section{Excellent Good Fair Poor}

\section{Appearance}

Grooming

Posture

Dress

Manners

\section{Communication}

Grammar

Non-verbal

Eye contact

Presentation

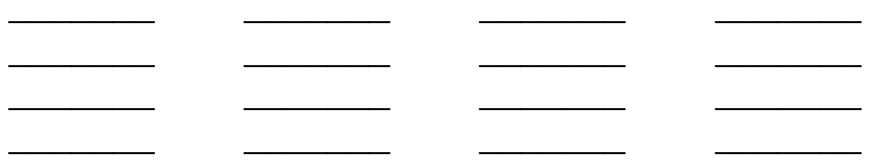

Personality

Attitude

Motivation

Enthusiasm

Sincerity

Maturity

Responsibility

Confidence

Dependability

Composure

\section{Goals}

Future goals Interest in job Knowledge

Set Plan

Result:

Hire for position

Not hire 


\section{References}

Boles, R. N. (1996). Edition. What Color Is Your Parachute? A Practical Guide For Job Hunters and Career Changers. Berkeley, CA: Ten Speed Press.

Fein, R. (1996). 101 Dynamite Questions to Ask at Your Job Interview. Manassas Park, VA: Impact Publications.

King, J. A. (1993). The Smart Woman's Guide to Interviewing and Salary Negotiation. Hawthorne, NJ: Career Press.

Talham. K. and Gentry, J. (Editors) Summer, 1997. The Latest Word: Tips for Making an Interview Experience Positive. In UF Perspective. Gainesville, FL: University of Florida Personnel Services.

von Raffler Engle, W. (1983). The Perception of Non-Verbal Behavior in the Career Interview. Philadelphia, PA: John Benjamin Publishing.

This document is FY350, Part 6 of an 8 part series developed for the Department of Family, Youth and Community Sciences, Cooperative Extension Service, Institute of Food and Agricultural Sciences, University of Florida.

Revised version prepared for electronic publication November 2001 by Elizabeth B. Bolton, professor, community development, Department of Family, Youth and Community Sciences, Extension Cooperative Service, Institute of Food and Agricultural Sciences, University of Florida, Gainesville, 32611-0310.

Original version prepared for publication May 1997 by Elizabeth B. Bolton, professor, community development, Department of Family, Youth and Community Sciences and George O. Hack, assistant in Department of Family, Youth and Community Sciences, Extension Cooperative Service, Institute of Food and Agricultural Sciences, University of Florida, Gainesville, 32611-0310.

The Institute of Food and Agricultural Sciences is an equal opportunity/affirmative action employer authorized to provide research, educational information and other services only to individuals and institutions that function without regard to race, color, sex, age, handicap, or national origin. For information on obtaining other extension publications, contact your county Cooperative Extension Service office.

Florida Cooperative Extension Service/Institute of Food and Agricultural Sciences/University of Florida/Christine Taylor Waddill, Dean 